УДК 378.147

DOI:

Андрій Плаксін, кандидат педагогічних наук, начальник навчально-методичного відділення Київського факультету Начіональної академії Начіональної гвардї України, м. Київ

\title{
СУТНІСНІ ХАРАКТЕРИСТИКИ ДИДАКТИЧНОЇ КУЛЬТУРИ МАЙБУТНІХ ВИКЛАДАЧІВ ЗАКЛАДІВ ВИЩОЇ ОСВІТИ МВС УКРАЇНИ
}

У статті розкрито сутність понять “культура”, “дидактична культура”, “дидактична культура майбутніх викладачів” з точки зору різних наукових підходів. Зроблено історико-педагогічний аналіз наукових основ розвитку дидактичної культури. Окреслено функиії дидактичної компетентності майбутніх викладачів. Визначено змістові компоненти дидактичної культури майбутнього викладача закладу вищої освіти зі специфічними умовами навчання в системі МВС Украӥни. Запропоновано авторське визначення поняття дидактична культура майбутніх викладачів закладів вищої освіти МВС України.

Ключові слова: дидактична культура, заклад вищьої освіти, культура, МВС Украӥни, професійна зрілість.

Jim. 13.

Andriy Plaksin, Ph.D. (Pedagogy), Head of the Teaching and Methodical Department of the Kyiv Faculty National Academy of National Guard of Ukraine, Kyiv

\section{THE ESSENTIALCHARACTERISTICS OFDIDACTIC CULTURE OFTHE FUTURE TEACHERS OF HIGHER EDUCATIONOFMINISTRY OF INTERNALAFFAIRS OF UKRAINE}

The article reveals the essence of the concepts "culture", "didactic culture", and "didactic culture of future teachers" in terms of different scientific approaches. The role of culture for personal formation and development is determined. The stages of actualization of pedagogical potential: accumulation, transformation, broadcasting are substantiated. The historical and pedagogical analysis of the scientific foundations of the development of didactic culture is made. The functions of the didactic competence of future teachers are outlined. The content components of the didactic culture of the future teacher of higher education institution with specific learning conditions in the Ministry of Internal Affairs of Ukraine such as: professional knowledge, pedagogical abilities, pedagogical skills, professional competence, creativity, personal qualities, pedagogical experience, pedagogical technique are determined. The author's definition of the concept of "didactic culture of future teachers of institutions of higher education of the Ministry of Internal Affairs of Ukraine is proposed". The value of the didactic competence of future teachers of higher education institutions is outlined. The information about such functions of didactic competence as: cognitive-epistemological, regulatory, invariant, integrative are presented. Theoretically substantiated the essential characteristics of the concept of "social professional maturity". The importance and significance of social-professional maturity for an officer of internal affairs bodies, which is part of the didactic culture of the future teacher of the Ministry of Internal Affairs of Ukraine is emphasized. Social maturity in the context of four aspects, namely: intellectual, political and moral maturity is considered. Socio-professional maturity of the personality of the employee of the internal affairs bodies, as neoplasms in the structure of the personality is characterized. The components of the general vocational and pedagogical culture: value-motivational, cognitive, technological, personal and creative are disclosed.

Keywords: culture, didactic culture, the institution of higher education, MIA of Ukraine, professional maturity.

П остановка проблеми. В умовах розбудови в Україні правової держави та громадянського суспільства, інтеграції в світове співтовариство об'єктивно підвищуються вимоги до рівня та якості професійної підготовки працівників правоохоронних органів, до всієї системи професійної освіти правоохоронців. У зв'язку з цим особливого значення набуває модернізація змісту, форм i методів підготовки майбутніх викладачів закладів вищої освіти МВС України, здатних не лише виконувати свої професійні обов'язки, але й володіти високим рівнем сформованості дидактичної культури. Процес підготовки майбугніх викладачів в умовах магістратури в цілому потребує формування в них даного виду культури, яка опосередкована педагогічним ідеалом цілісної особистості викладача, спільно 3 багатим потенціалом професійних знань і дидактичних умінь.

Відповідно до вимог, задекларованих у Законі України “Про вищу освіту” (2014р.), Національної стратегії розвитку освіти в Україні на період до 2021 р., сьогодні провідним критерієм підготовленості майбутніх викладачів закладів вищої освіти МВС України до освітньої діяльності 


\section{СУТНІСНІ ХАРАКТЕРИСТИКИ ДИДАКТИЧНОЇ КУЛЬТУРИ МАЙБУТНІХ ВИКЛАДАЧІВ ЗАКЛАДІВ ВИЩОЇ ОСВІТИ МВС УКРАЇНИ}

$\epsilon$ спрямованість особистості на засвоєння ціннісних орієнтацій професійної діяльності, сукупність професійних і дидактичних знань, постійне вдосконалення дидактичних здібностей, умінь і навичок таїхньої реалізації шляхом творчої продуктивної діяльності.

Аналіз основних досліджень та публікацій. Дослідженню дидактичної культури як складової професійної діяльності викладача присвячені роботи В. Гриньова, Я. Коменського, Л. Тархан, К. Ушинського, І. Шамсутдінової та ін. Проблемою розвитку окремих складових професійної культури викладачів закладів вищої освіти МВС України опікується ряд науковців, зокрема: В. Бакуменко, О. Бандурка, В. Барковський, П. Білий, С. Бублік, T. Гороховська, I. Зеленко, М. Ібрагімов, В. Куличенко, І. Михайліченко, А. Морозов, А. Романова, Б. С'єдін, О. Синчишина, С. Сливка, Г. Яворська та ін.

Мета статті-розкрити сугнісні характеристики дидактичної культури викладачів закладів вищої освіти МВС України.

Виклад основного матеріалу. Термін “культура" належить до числа багатозначних, i пояснюється це тим, що сама культура - вкрай складне, багатогранне явище, що виражає усі сторони людського буття $[9,130]$.

У дослідженнях представників діяльнісного підходу (Є. Балер, В. Давидович, М. Злобін, М. Каган, Л. Каган та ін.) культура розуміється як специфічний спосіб діяльності, що забезпечує збереження та відтворення цивілізації в умовах мінливості навколишнього світу за рахунок розгляду людини як суб'єкта культурноісторичного процесу. Іншими словами, під культурою слід розуміти “такий спосіб творчої діяльності особистості, за допомогою якого передбачається саме позитивне перетворення в різних сферах буття людини (культурна діяльність)", зокрема на рівнях:

- потреб і безпосередніх засобів їхньої реалізації через звичні, повсякденні види діяльності;

- виробництва - виготовлення знарядь, засобів праці, їі технологій;

- системи суспільних відносин;

- суспільної свідомості (буденної, професійної та науково-теоретичної) [11].

В узагальненому представленні роль культури для людини полягає в надбанні досвіду, формуванні індивідуальної картини світу і залученні до цінностей. Таким чином, за допомогою культури людина набуває ставлення до загальнолюдського і власного досвіду і світу в цілому $[1 ; 2 ; 3]$.

Ученими встановлено, що актуалізація педагогічного потенціалу культури відбувається лише в діяльності у три послідовних етапи: акумулювання, трансформування і транслювання.

Коротко суть цих етапів можна представити наступним чином. Перший етап - акумулювання, заснований на механізмах розпредмечування, тобто “перекладу” змісту існуючого як зовнішнього по відношенню до особистості світу в свідомість у результаті сприйняття і пізнання культури, аналізу і оцінки цього змісту - залежно від характеру і виду педагогічного потенціалу культурного артефакту. Другий етап трансформування, являє собою педагогічну адаптацію змісту педагогічного артефакту і створення умов для його актуалізації. Трансформування культурного артефакту здійснюється не будь-якою людською діяльністю, а саме педагогічною діяльністю. Знаннєвий компонент культури на рівні педагогічної діяльності втілюється в категорії “зміст освіти”, ціннісний компонент культури утворює нормативно-цільовий компонент педагогічної діяльності.

Третій етап - транслювання, грунтується на механізмі опредмечування, тобто включення матеріальних та ідеальних артефактів в освітній процес для досягнення педагогічних цілей. Конкретно механізм транслювання визначається безпосередньо характером потенціалу, а саме: артефакти, що володіють реальним педагогічним потенціалом, актуалізуються способами диференціації-виділення в культурі компонентів, що забезпечують досягнення запланованого педагогічного результату. Культурні артефакти 3 формальним педагогічним потенціалом актуалізуються способами інтеграції, тобто включенням в освітній процес існуючих, але не задіяних раніше компонентів культури $[5,5]$.

3 огляду на вищесказане, можна вважати, що дидактична культура як науково-педагогічний феномен, у теоретичному плані грунтується на великому педагогічному потенціалі культури, механізмах його акумулювання, трансформування і транслювання, які $є$ фактором професійного становлення фахівця педагогічного профілю, забезпечуючи формування його дидактичної культури.

Історико-педагогічний аналіз наукових основ розвитку дидактичної культури слід, на наш погляд, почати зі звернення до ідей засновника дидактики Я. Коменського.У “Великій дидактиці” ним розроблені “загальні вимоги навчання та учіння, тобто як вчити і вчитися напевно, щоб не міг не наслідувати позитивний результат". Розкриваючи по суті зміст 


\section{СУТНІСНІ ХАРАКТЕРИСТИКИ ДИДАКТИЧНОЇ КУЛЬТУРИ МАЙБУТНІХ ВИКЛАДАЧІВ ЗАКЛАДІВ ВИЩОЇ ОСВІТИ МВС УКРАЇНИ}

дидактичної культури, Я. Коменський пише: “Жорстокий той вчитель, який, запропонувавши учням роботу, не роз'яснює достатньо, в чому вона полягає, не показує, як іiї виконувати, а ще гірше того - допомагає їм при перших спробах, але зобов'язує їх самих працювати щосили i хвилюється та лютішає, якщо вони щось роблять не зовсім правильно... Вчитель є помічник природи, а не її владика, їі засновник, а не перетворювач, тому якщо він бачить, що хтонебудь з учнів береться за що-небудь без достатніх до того здібностей, то нехай не підганяє його вперед...” [6, 119].

Засновником вітчизняної теорії професійнопедагогічної, у т. ч., і дидактичної культури, на справедливу думку багатьох дослідників, є К. Ушинський. Найбільш детально різні аспекти цієї проблеми розкриті у його статті “Про користь педагогічної літератури”. Цю літературу він вважав засобом формування i передачі педагогічної культури: "Педагогічна література повинна виражати, зберігати і робити для кожного доступним результати педагогічної практики, на підставі яких тільки і можливий розвиток суспільного виховання" $[10,28]$.

На думку В. Гриньова, дидактична компетентність особистості - це інтегративна якість, яка проявляється в теоретичній i практичній готовності особистості до дидактично-професійної діяльності, спрямованої на вирішення різноманітних дидактичних завдань, самореалізації в творчому навчальному процесі [4].

Сутність дидактичної компетентності визначається І. Шамсутдіновою як "можливість оперативно, обгрунтовано, зважено i безпомилково приймати дидактичні рішення, знаходити найкоротший шлях рішення дидактичного завдання, вибирати адекватні для тих чи інших умов методи, прийоми і засоби навчання" $[12,222]$. В. Лебєдінцев сутність дидактичної компетентності вбачає в “побудові індивідуальних навчальних стратегій по відношенню до різних учнів” [7, 37].

Деякі дослідники говорять про значення дидактичної компетентності педагога для його професіоналізму, описують іiї конкретні функції. Л. Тархан вважає, що дидактична компетентність виконує пізнавально-гносеологічну, регулятивну, інваріантну й інтегративну функції. Пізнавальногносеологічна функція, на думку автора, полягає в тому, що дидактична компетентність дозволяє досліджувати, системно описувати та пояснювати виникаючі проблеми освіти з позиції сучасної науки, забезпечує залучення сучасного знання для ефективного формування та приєднання творчого потенціалу людини в інтересах професії та задоволення комплексу його потреб. Регулятивна функція полягає в тому, що вона відіграє роль внутрішньої детермінанти суб'єкта, яка обумовлює системний, упорядкований i цілеспрямований характер формування, розвитку й оптимального залучення його потенціалу; інваріантна функція означає просування людини до особистих вершин розвитку та самореалізації; інтегративна функція забезпечує цілісність процесу розвитку і використання людиною інноваційно-акмеологічної культури [8].

Трактуючи поняття педагогічної майстерності, iii змісту та структури, можна виділити ті їі компоненти, які за своєю суттю можуть становити зміст дидактичної культури. До таких компонентів ми можемо віднести:

- фахові знання (володіння змістом навчального предмета і методикою його викладання);

- педагогічні здібності(дидактичні, організаторські, комунікативні, перцептивні, сугестивні, науковопізнавальні);

- педагогічні вміння (уміння організувати власну педагогічну діяльність, навчальнопізнавальну діяльність учнів, формувати мету навчання);

- професійну компетентність (знання педагогіки, зокрема дидактики);

- творчість (креативність та умови її реалізації в освітньому процесі);

- особистісні якості;

- педагогічний досвід (поглиблення фахових знань, розширення ерудиції, удосконалення методики та технології викладання);

- педагогічну техніку.

Безсумнівну користь для нашого дослідження має докторська дисертація Г. Яворської, присвячена теоретичним і методологічним основам соціально-професійної зрілості курсантів закладів вищої освіти МВС України. У роботі не досліджується дидактична культура майбутніх викладачів правових дисциплін як предмет. Водночас автор виокремлює одне з протиріч, які необхідно подолати: “між необхідністю впровадження сучасних педагогічних технологій у закладах вищої освіти закритого типу та недостатньою дидактичною підготовкою викладачів-юристів закладів вищої освіти України" $[13,2]$. В роботі, яка аналізується, для нас представляють інтерес три аспекти. Поперше, теоретичне уявлення поняття “соціальнопрофесійна зрілість працівника органів внутрішніх справ, яка $є$ складовою дидактичної культури майбутнього викладача закладу вищої освіти МВС 


\section{СУТНІСНІ ХАРАКТЕРИСТИКИ ДИДАКТИЧНОЇ КУЛЬТУРИ МАЙБУТНІХ ВИКЛАДАЧІВ ЗАКЛАДІВ ВИЩОЇ ОСВІТИ МВС УКРАЇНИ}

України"; по-друге, педагогічна модель формування соціально-професійної зрілості курсантів закладів вищої освіти України; по-третє, методика формування соціально-професійної зрілості майбутнього юриста в освітньому процесі закладу вищої освіти.

Кожен із цих аспектів, на наш погляд, співвідноситься з предметом нашого дослідження. Автор розглядає досягнення особистістю певного рубежу соціальної зрілості в чотирьох основних аспектах: інтелектуальна, політична, професійна і моральна зрілість. Як основні компоненти вони не складають механічної суми, а об'єднуються в певну систему, що має внутрішню органічну

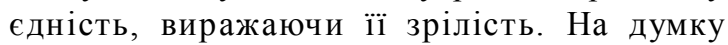
Г. Яворської, для молоді, яка професійно навчається, певний рівень соціальної зрілості повинен відображати:

а) можливість і здатність самостійно набувати знання, потребу в безперервній освіті, найважливішою умовою якої є ставлення до навчання як необхідної діяльності впродовж усього життя та наявність умінь і навичок самоосвіти (інтелектуальна зрілість);

б) готовність творчо працювати 3 повною віддачею в інтересах суспільно значущої мети, адже ставлення особистості до праці та суспільної діяльності є пробним каменем ії зрілості; освоєння професії, обраної відповідно до суспільних потреб і особистих схильностей, наявність для цього необхідних знань, умінь і навичок, здатність переносити їх у нові види діяльності (професійна зрілість);

в) усвідомлення виконання своїх прав i обов'язків, глибока переконаність в ідеалах і готовність до їхньої реалізації (політична зрілість).

Виходячи з цього, автор розуміє під соціальнопрофесійною зрілістю особистості працівника органів внутрішніх справ, як новоутворення у структурі особистості, яка виявляє себе в спроможності робити свідомий і обгрунтований вибір щодо дій, визначених службовопрофесійним обов'язком. Отже, соціальнопрофесійна зрілість - це становлення особистості як цілісної, відносно стійкої (усталеної) системи, пов'язаної з усвідомленням нею свого місця, ролі, функцій у професії, в суспільстві, в колективі $[13,17]$.

Г. Яворська виділяє низку характеристик професійної зрілості, які цілком можуть бути застосовані і для характеристики викладацької діяльності майбутнього викладача закладу вищої освіти системи МВС, у т. ч. його дидактичної культури. Вона підкреслює: "Професійна зрілість передбачає: соціальну зрілість (володіння правовими нормами, засобами спільної професійної діяльності та співробітництва, прийнятими у суспільстві прийомами професійного спілкування тощо); особистісну зрілість (володіння засобами самовираження і саморозвитку); діяльнісну зрілість (вміння на високому рівні діяти професійно, здатність до самореалізації та саморозвитку в межах професії, до творчих проявів власної індивідуальності)" [13, 18].

Дидактична культура майбутнього викладача закладу вищої освіти системи МВС України є складовою загальної професійно-педагогічної культури, що має такі компоненти, як: ціннісномотиваційний, когнітивний, технологічний, особистісно-творчий.

Сутність ціннісно-мотиваційного компонента дидактичної культури полягає в сформованості у майбутнього викладача сукупності педагогічних цінностей як норм, що регламентують його освітню діяльність (цілей, засобів, відносин, якостей) і що породжує в свідомості викладача особистісну систему ціннісних орієнтацій і позитивну мотивацію до освітньої діяльності.

Когнітивний компонент включає в себе сукупність методологічних, загальнотеоретичних, дидактичних, методичних знань, що забезпечують основу дидактичної компетентності майбутнього викладача. При цьому ядром когнітивного компоненту виступають дидактичні знання, що відображають сучасні теорії, концепції, закономірності, принципи, форми та методи організації освітнього процесу.

Основою технологічного компонента виступають дидактичні умови (гностичні, проектувальні, конструктивні, організаторські, комунікативні), володіння якими дозволяє майбутнього педагогу здійснювати процес навчання курсантів, моделюючи оптимальні форми, методи, прийоми і способи взаємодії з тим, кого навчає.

Особистісно-творчий компонент дидактичної культури передбачає сформованість власних авторських інноваційних елементів дидактичного процесу, високий ступінь особистої творчості в освоєнні інноваційних методів і прийомів навчання, постійний розвиток креативного педагогічного мислення.

Висновки. Таким чином, у нашому авторському трактуванні дидактична культура майбугніх викладачів закладів вищої освіти МВС України - це складова частина загальної професійно-педагогічної культури, яка $\epsilon$ логіко-структурованим особистісним утворенням, що включає в себе синтез таких взаємопов'язаних компонентів, як ціннісно-мотиваційний, когнітивний, технологічний, особистісно-творчий, наявність і високий ступінь 


\section{СУТНІСНІ ХАРАКТЕРИСТИКИ ДИДАКТИЧНОӤ КУЛЬТУРИ МАЙБУТНІХ ВИКЛАДАЧІВ ЗАКЛАДІВ ВИЩОЇ ОСВІТИ МВС УКРАЇНИ}

сформованості яких є визначальною умовою успішного здійснення навчальної діяльності майбутнього викладача закладу вищої освіти системи МВС України.

Перспективи подальших наукових розвідок вбачаємо у розробці, експериментальній перевірці та впровадженні в освітній процес закладів вищої освіти авторської моделі дидактичної культури майбутнього викладача вищого навчального закладу зі специфічними умовами навчання системи МВС.

\section{ЛІТЕРАТУРА}

1. Бенин В.Л. Педагогическая культурология / В.Л. Бенин. - Уфа: Изд-во БГПУ, 2004. - 515 с.

2. Гайсина Г.И. Культурологический подход в теории и практике педагогического образования: дис. .. докт. пед. наук: 13.00.08 / Г.И. Гайсина. - М., 2002. $-354 \mathrm{c}$.

3. Гершунский Б.С. Философия образования для XXI века (в поисках практико-ориентированных образовательных концепций) / Б.С. Гершунский. - М.: Совершенство, 1998. - 608 с.

4. Гриньов В.Й. Формування дидактичної культури майбутнього вчителя: дис.. ... канд. пед. наук: 13.00.04 / В. Й. Гриньов. - Х., 2003. - 179 с.

5. Киселева О.О. Педагогический потенциал культуры - фактор профессионального становления специалиста / О.О. Киселева, О.М. Позднякова // Человек и образование. - 2008. - № 4. - С. 3-6.

6. Коменский Я.А. Великая дидактика / Я.А. Коменский // Избранные педагогические сочинения: в 2-х т. Т. 1. - М.: Педагогика, 1982. - С. 242-346.

7. Лебединцев В.Б. Коллективные учебные занятия как средство обеспечения индивидуальных учебных траекторий учащихся малочисленных сельских школ: дис. ... канд. пед. наук: 13.00.01 / В.Б. Лебединцев. Красноярск, 2008. - 212 с.

8. Тархан Л.3. Дидактическая компетентность инженера-педагога: теоретические и методические аспекты: монография / Л.З. Тархан. - Симферополь: КРП “Издательство “Крымучпедгиз”, 2008. - 424 с.

9. Тернопільська В.І. Культура особистості школяра: постановка проблеми /В. І. Тернопільська // ВІСНИК Житомирського державного університету імені Івана Франка, 2005. Вип. 24. - С. 130-133.

10. Ушинский К.Д. О пользе педагогической литературы / К.Д. Ушинский // Собрание сочинений в 11 т. - М.-Л.: Наука, 1948-1951. - Т.2. - С. 15-42.

11. Цокур О.С. Щодо визначення сутності дидактичної та науково-дослідницької культури викладача вищого навчального закладу / О.С. Цокур / / Вісник національної академії Державної прикордонної служби України. Педагогічні науки. 2010. - Вип. 2 [Електронний ресурс]. - Режим доступу: ht t p :// nbuv.gov.ua/j-pdf/ Vnadps_2010_2_22.pdf

12. Шамсугдинова И.Г. Дидактическая компетентность учителя / И. Г. Шамсугдинова // Высшее педагогическое образование в России: традиции, проблемы, перспективы: тезисы междунар. науч.-практ. конф.: в 2-х ч. - М., 1997. - Ч. 1. - С. 219-221.

13. Яворська Г.Х. Теоретичні та методичні засади формування соціально-професійної зрілості курсантів вищих навчальних закладів МВС України: автореф. дис. ... д-ра пед. наук: спец. 13.00.04 “теорія та методика професійної освіти” / Г.Х. Яворська. - К., 2006. -45 c.

\section{REFERENCES}

1. Benin, V. L. (2004). Pedagogicheskaja kulturologia [Pedagogical culturology]. Ufa: BGPU Pudl., 515 p.[in Russian].

2. Gajsina, G. I. (2002). Kulturologicheskij podhod v teorii i praktike pedagogicheskogo obrazovania [Cultural approach in the theory and practice of teacher education]. Doctor's thesis. Moscov, 354 p. [in Russian].

3. Gershunskij, B. S. (1998). Filosofija obrazovanija dlja XXI veka (v poiskah praktiko-orientirovannyh obrazovatelnyh koncepcij) [The philosophy of education for the 21 st century (in search of practical-oriented educational concepts]. Moscov: Perfection, 608 p. [in Russian].

4. Hrynov, V. Y. (2003). Formuvannia dydaktychnoi kultury maibutnoho vchytelia [Formation of the didactic culture of the future teacher]. Candidate's thesis. Kharkiv, 179 p.[in Ukrainian].

5. Kiseleva, O. O. \& Pozdnyakova, O. M. (2008). Pedagogicheskij potencial kultury - faktor professionalnogo stanovlenija specialista [Pedagogical potential of culture - the factor of professional becoming a specialist]. Person and Education, no. 4, pp. 3-6.[in Russian].

6. Komenskij, Ja. A. (1982). Velikaja didaktika [The great didactic]. Selected pedagogical compositions: in 2 Vol., vol. 1. Moscov: Pedagogue, pp. 242-346.[in Russian].

7. Lebedincev, V. B. (2008). Kollektivnye uchebnye zanjatija kak sredstvo obespechenija individualnyh uchebnyh traektorij uchashhihsja malochislennyh selskih shkol [Collective training as a means of providing individual study paths for students in small rural schools]. Candidate's thesis. Krasnojarsk, 212 p. [in Russian].

8. Tarhan, L. Z. (2008). Didakticheskaja kompetentnost inzhenera-pedagoga: teoreticheskie i metodicheskie aspekty [Didactic competence of the engineer-teacher: theoretical and methodical aspects]. Simferopol: KRP "Publishing house "Krymuchpedgiz", 424 p. [in Russian]

9. Ternopilska, V. I. (2005). Kultura osobystosti shkoliara: postanovka problemy [Schoolboy personality culture: problem statement]. BULLETIN of Zhytomyr State University named after Ivan Franko. Vol. 24, pp. 130-133.[in Ukrainian].

10. Ushinskij, K. D. (1948-1951). O polze pedagogicheskoj literatury [About the benefits of pedagogical literature].Collected works in $11 \mathrm{Vol}$. Moscov- L.: Science, vol. 2, pp. 15-42. [in Russian].

11. Tsokur, O. S. (2010). Shchodo vyznachennia sutnosti dydaktychnoi ta naukovo-doslidnytskoi kultury vykladacha vyshchoho navchalnoho zakladu 


\section{ІНШОМОВНА ОСВІТА МАЙБУТНЬОГО ЛІКАРЯ У ВЕЛИКІЙ БРИТАНІЇ}

[Concerning the definition of the essence of the didactic and research culture of a teacher of a higher educational institution]. Bulletin of the National Academy of the State Border Guard Service of Ukraine. Pedagogical sciences, vol. 2 [Electronic resource]. Available at: http:// nbuv.gov.ua/j-pdf/Vnadps $2010 \quad 2 \quad 22 . p d f$ [in Ukrainian].

12. Shamsutdinova, I. G. (1997). Didakticheskaja kompetentnost uchitelja [Didactic competence of the teacher]. Vysshee pedagogicheskoe obrazovanie $v$ Rossii: traditsii, problemy, perspektivy: tezisy mezhdunar. nauch.-prakt. konf.: $v$ 2-kh ch. - Higher pedagogical education in Russia: traditions, problems, prospects: Abstracts of Papers of the International Scientific Practical Conference: in 2 parts, (Part. 1, pp. 219-221). Moscov. [in Russian].

13. Iavorska, H. Kh. (2006). Teoretychni ta metodychni zasady formuvannia sotsialno-profesiinoi zrilosti kursantiv vyshchykh navchalnykh zakladiv MVS Ukrainy [Theoretical and methodical principles of formation of socio-professional maturity of cadets of higher educational institutions of the Ministry of Internal Affairs of Ukraine]. Doctor's thesis. Kyiv, 45 p.[ in Ukrainian].

Стаття надійшла до редакції 14.02.2018

УДК 378.147:61:81’243(410)

DOI:

Камілла Магрламова, кандидат педагогічних наук, викладач кафедри мовної підготовки ДЗ “Дніпропетровська медична академія МОЗ України”

\section{ІНШОМОВНА ОСВІТА МАЙБУТНЬОГОЛІКАРЯ У ВЕЛИКІЙ БРИТАНІЇ}

На сучасному етапі розвитку економіки Украӥни зростає потреба в кваліфікованих фахівиях, які мають високии рівень не тільки мовної підготовки але й іншомовної освіти. Здійснюється розкриття особливостей та тенденцій розвитку іншомовної підготовки майбутніх лікарів, як процесу кваліфікованого опанування іноземної мови, щцо є засобом здобування як фахових, так $і$ загальних знань. Обгрунтовуються важливі аспекти в іншомовній підготовиі майбутніх лікарів та надаються основні факти, характерні особливості іншомовної освіти майбутнього лікаря у Великій Британії.

Ключові слова: майбутній лікар, іншомовна освіта, тендениії розвитку, професійне становлення, професійне навчання.

Jim. 12.

Kamilla Mahrlamova, Ph.D. (Pedagogy), Lecturer of the Language Training Department State Establishment "Dnipropetrovsk Medical Academy of the Ministry of Health of Ukraine"

\section{THE FOREIGN-LANGUAGE EDUCATION OF A FUTURE DOCTOR IN THE UK}

At the current stage of development of the Ukrainian economy, it is the growing need of qualified specialists with a high level of linguistic training and foreign language education. The disclosure of peculiarities and trends of the development of foreign language training of future doctors as a process of qualified foreign language learning, which is a means of acquiring both professional and general knowledge, is underway. The article substantiates the important aspects of foreign language training of future doctors and provides the basic facts, characteristics of the future education of a foreign doctor in the UK.

The unification of Europe and the deepening of international cooperation, the demand of the European labor market put forward the high demands for the foreign language skills in modern physicians. The process of studying becomes an essential element of general education and its importance in European educational institutions is constantly increasing. The requirements of the European Union contain the provision that as the largest European citizens have to speak two foreign languages, except for their native language.

Keywords: a future doctor, foreign language education, the development of tendencies, the professional formation, the vocational training.

A ктуальність дослідження. Об'єднання Європи та поглиблення міжнародного співробітництва, попит європейського ринку праці висувають високі вимоги до володіння іноземними мовами у сучасних лікарів. Процес навчання перетворюється в істотний елемент загальної освіти і значення його в європейських освітніх закладах постійно зростає. У вимогах Європейського Союзу міститься положення про те, що як найбільше громадян Європи повинні володіти двома іноземними мовами, крім рідної.

Напрями європейського співробітництва в освітній сфері на початку нового тисячоліття визначені програмою “Освіта і професійна підготовка 2010” (Education \&Training 2010), що була затверджена СС у 2001 р. Програма стала складовою системи європейського співробітництва, 